\title{
HUSBANDS AND WIVES: A CORRECTION
}

\author{
Scott Johnson
}

In my December 1993 article, "Husbands and Wives" (Johnson, 1993), which examined Woody Allen's (1992) film "Husbands and Wives" from a generally Bowenian point of view, I unwittingly misinterpreted a statement made by one of the film's female characters, Sally, about why she was unable to have an orgasm while making love with Michael, a character with whom she is temporarily involved. "I was trying to," I quoted her as saying to an unseen interviewer in the film. "I came close" (p. 452). Asked by the interviewer what makes it so difficult, Sally goes on to say, as I quoted in my article, "My mind just gets racing with thoughts. You'd laugh if I told you. I guess I'm mentally hyperactive" (p. 452). When the interviewer asks Sally what she thinks about during sex, her thoughts and the camera shift to a scene in which she and Michael are making love, and she ${ }^{1}$ states in a voice-over, as I cited in my article:

I thought that I liked what Michael was doing, and it felt different from Jack [Sally's estranged husband]. More gentle, and more exciting. And I thought how different Michael was from Jack, how much deeper his vision of life was. And I thought Michael was a hedgehog, and Jack was a fox. And then I thought Judy was a fox, and Gabe was a hedgehog. And I thought about all the people I knew, and which were hedgehogs, and which were foxes. Al Simon, a friend, was a hedgehog, and his wife Jenny was a hedgehog, and Cindy Salkind was a fox. And Lou Petrino was a hedgehog (p. 453).

In my original discussion, I suggested that Sally's anorgasmia, along with other symptoms such as her use of "mental hyperactivity"

Scott Johnson, $\mathrm{PhD}$, is director of clinical training, Marriage and Family Therapy PhD Program, Virginia Polytechnic Institute \& State University, Blacksburg, VA 24061-0512.

${ }^{1}$ In my original article in the last sentence on page 452 , due to my oversight, the name "Judy" is mistakenly substituted for "Sally." Judy, a different character in the movie, is played by Mia Farrow. Sally is played, of course, by Judy Davis. 
to avoid sexual feelings and her characterization by another character as being "cold in bed," could be seen as indications of possible previous sexual abuse. I specifically interpreted Sally's reference to "hedgehogs and foxes," moreover, as "juvenile" in character, suggesting that it might be "a protection developed in her childhood as a psychic shield against unavoidable sexual assault" (p. 454).

While this view of "hedgehogs and foxes" obviously made sense to me at the time, and no readers of my article to my knowledge have challenged it, I subsequently have learned that it is clearly wrong. For though it is plausible to say that Sally's character shows signs of possible prior sexual abuse, and it is reasonable to wonder about such abuse's origins, the reference to hedgehogs and foxes cannot be taken as evidence of childhood abuse, since Allen, who constantly makes literary references in his films, most likely uses it to allude to an essay by the British philosopher, Sir Isaiah Berlin (1953/1993) called "The Hedgehog and the Fox."

The title of Berlin's essay is taken from a much commented on fragment from the 7th century (BC) Greek soldier-poet Archilocus of Paros: "The fox knows many things but the hedgehog knows one big thing" (as cited in Berlin, 1953/1993, p. 3). Berlin uses this line to explore the thinking of the Russian novelist Leo Tolstoy, who, Berlin says, was at bottom a "fox" who wanted to be a "hedgehog." That is, while searching ceaselessly for a single universal truth-the "one big thing" of the hedgehog, Tolstoy's novels exemplify the "many things" of the fox-the multiple truths of a brilliant observer of humanity's variety.

Sally's reference to Berlin's essay in the middle of her lovemaking, while still clearly a defense against feeling-an obvious attempt to be "rational" in the midst of an emotional experience-cannot therefore be reasonably seen as juvenile (even if one argues that a character like hers might be expected to have first read Berlin's piece in college or preparatory school). Thus, while Sally still displays characteristics consistent with the possibility of prior sexual assault-her anorgasmia, her intellectualizing, the long-term sexual dysfunction in her 20 year marriage as well as in her relationship with MichaelAllen (arguably himself a fox who can create a myriad of answers to the hedgehog-like question of Husbands and Wives: what is this thing called love?) gives us no way of knowing if such abuse may have occurred earlier or later in Sally's life.

My error illustrates a danger, I think, of something else I discussed in my paper: the tendency of great art to invite broad specula- 
tion. While I have no doubt that art still does this, and always will, nor any question of the immense mutual contributions art and family therapy can make to each other and to the general understanding of human behavior through such inquiries, my mistake points out again to me a lesson from my days as a teacher of literature and film-the critical importance of considering all possible meanings of a text or script, those which may undermine as well as support our views.

This lesson has, I think, clinical parallels, none so obvious, perhaps, as the need to question our clients directly about assumptions that we make about them-to ask the real Sallies who walk into our offices if their references to hedgehogs and foxes have anything to do in their minds with their childhoods-rather than leave untested our hypotheses about the causes of our clients' behavior. Particularly with a subject such as child sexual abuse, which my article partially focused on-an area where therapists have at times substituted their beliefs about their clients' experiences for reality-this lesson seems critical.

My apologies for this error to any readers who may have been misled by it, as well as to Bill Nichols, Contemporary Family Therapy's editor, and the anonymous reviewers who initially read my piece. My apologies also for the time it has taken to make this correction, which was delayed by my having to search for Berlin's work and then make the time to study it. And my thanks to my wife, Dr. M. K. Johnson, who first brought the existence of Berlin's essay to my attention some months after my article appeared.

\section{REFERENCES}

Allen, W. (writer \& director). (1992). Husbands and wives. Culver City, CA: TriStar Pictures.

Berlin, I. (1993). The hedgehog and the fox. Chicago: Elephant Paperback. (Original work work published 1953).

Johnson, S. (1993). Husbands and wives. Contemporary Family Therapy, 15, 443-458. 